\title{
Logistics Outsourcing: Why Do Not Some Italian SMEs Adopt the Externalization?
}

\author{
Andrea Payaro ${ }^{1} \&$ Anna Rita Papa ${ }^{1}$ \\ ${ }^{1}$ P\&P Consulting \& Service, Via Aldo Moro 37, 35020 Legnaro PD, Italy \\ Correspondence: Andrea Payaro, Ph.D., P\&P Consulting \& Service, Via Aldo Moro 37, 35020 Legnaro PD, \\ Italy.
}

Received: May 9, 2017

Accepted: June 20, 2017

Online Published: June 29, 2017

doi:10.20849/abr.v2i2.164

URL: https://doi.org/10.20849/abr.v2i2.164

\begin{abstract}
Logistics is a one of the common function that companies usually outsourced. The decision to keep this function in-house or contract with one or many third-party logistics (3PL) companies is entirely strategic and can dramatically impact any organization's bottom line. 3PL users report an average of $44 \%$ of their total logistics expenditures are related to outsourcing. $72 \%$ of firms are increasing their use of outsourced logistics services in 2015, which is up slightly from the average reported in recent years. Most developed outsourcing logistics market belongs to the U.S. with $88 \%$. It is followed by Asia $48 \%$, and Europe - $46 \%$ (O'Reilly, 2010). In Italy some industries can reach the $70 \%$, in particular food, groceries and fashion (Osservatorio Contract Logistics del Politecnico di Milano). There are many researches about logistics and large enterprises. There are less studies about Small and medium-sized enterprises (SMEs) and logistics outsourcing. SMEs play a major role in the Italian economic system. Their business activities have become an important component of the Italian economy.

This paper aims to depict the adoption level of outsourcing by Italian SMEs. By direct interviews to 28 companies' representatives we investigate which services or processes are outsourced. We investigate the reasons why companies adopt or don't adopt the externalization. Moreover, for every company we calculate the logistics costs of simple logistics processes. In effect, we wish to compare the logistics costs communicated by the firms and the same costs calculated with ABC (Activity Based Cost) model. This research demonstrate that SMEs adopt 3PLs only for transportation. SMEs do not know all the logistics services offered by 3PLs and SMEs think the services are dedicated only to large enterprises. Finally, many companies are not able to calculate logistics costs, then they cannot compare a 3PL offer with their real costs.
\end{abstract}

Keywords: SME, logistcs outsourcing, logistics costs

\section{Introduction}

Logistics encompasses all of the information and material flows throughout an organization. It includes everything from the movement of a product or from a service that needs to be rendered, through to the management of incoming raw materials, production, the storing of finished goods, its delivery to the customer and after-sales service (Pollitt, 1998). The scope of logistics has changed since the emergence of new technologies and strategic alliances in order to compete on flexibility and responsiveness. The growing importance of logistics arises from companies becoming globalized to gain access to new markets, realize greater production efficiencies, and tap technological competencies beyond their own geographical borders (McFarlan, 1984; Bovet, 1991; Cooper, 1993; Fawcett et al., 1993).

Logistics is a one of the common functions that companies usually outsourced. There are a lot of definitions available for 3PL, describing in different contexts. Hilletofth and Hilmola (2010) suggest that the outsourcing of logistics has received considerable attention in literature. For example Andersson (2003) provides a very basic definition of logistics outsourcing: "Third-party logistics (3PL) are activities carried out by an external company on behalf of a shipper and consisting of at least provision of management of multiple logistics services. These activities are offered in an integrated way, not on a stand-alone basis. The co-operation between the shipper and the external company is an intended continuous relationship". And according to Lieb (1992, pp. 29) logistics outsourcing is "the use of external companies to perform logistics functions that have traditionally been performed within an organization. The functions performed by the third party can encompass the entire logistics process or selected activities within that process." 
Hrušecká et al. (2015) show which logistics activities are the most often outsourced:

- Transport and shipment

- Warehousing and inventory

- Information systems

- Other, related to value added services (Product returns, Product assembly \& installation, Labelling, Customisation, Assembly, Packaging)

Aldin and Stahre (2003) presented a conceptual model for logistics supply chain management, with a special focus on 3PL. This model consists of three major components: (1) logistics structure; (2) logistics processes and related activities; and (3) information and reporting systems. All three components are essential for a successful 3PL operation. Some of the logistics activities include transport, transshipment, maintenance of the inventory, and the assembling or reconditioning of products.

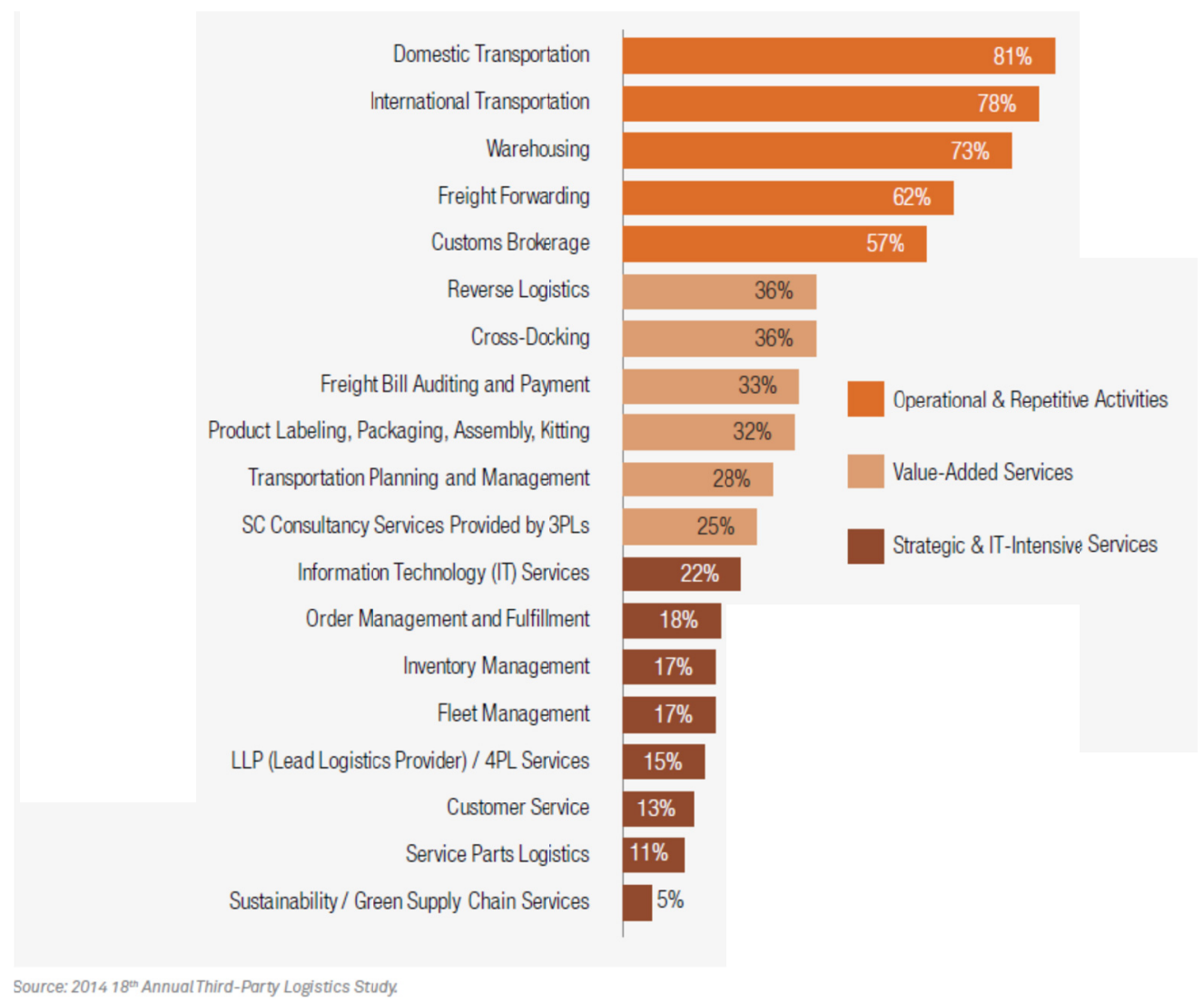

Figure 1. 2014 Third-party logistics study presents the main services offered by a 3PL

According to the literature based by Chopra and Meindl (2010) the 3PL companies conventionally provide services like transportation, warehousing and Information technology in SC process. Due to the influence of globalization and competition to provide cost effective solutions, now 3PL providers are focusing on different functions in SC.

There are several reasons for which companies decide to outsource, but the following four reasons encompass several other reasons for the company's motive to outsource, they are (Wilding and Juriado, 2004):

- Cost. 3PL has less costs than shipper because it has economies of scale. In addition outsourcing of activities to 3PL providers can reduce logistics costs by an average of $11 \%$ (Commonwealth Business Media Inc., 2006). Moreover shipper should transform fixed costs in variable costs (Persson and Virum, 2001). 
- Flexibility. It is the ability of a company to adapt to changing circumstances and thus remain a profitable enterprise (Scott et al., 2011). 3PL typically specialize in integrated transportation and warehousing services that can be scaled and modified according to customer's requirements in much efficient manner with higher quality (Hilletofth and Hilmola, 2010).

- Core competencies. Company relies on 3PL activities not core competence. In this way Company can concentrate its resouces on core competences. According to Hamel and Prahalad (1990), the core competencies constituting the basis of resources theory make it possible for the company to enter and hold its ground in competition in various market segments.

- Technology. Firms can hire the services of third party logistics at their ease rather than to implement and develop new technologies in house, as it would be costly and time consuming activity. Alternatively, resourcefulness of third parties facilities firms to develop in technology, location, control and rotating permanent costs into changeable costs. Third party logistics providers are capable enough to reconstitute the delivery system to change to technological advances or altering markets (Trunick, 1989).

\section{Outsourcing and SMEs}

There are many researches about logistics and large enterprises. There are less studies about Small and medium-sized enterprises (SMEs) and logistics outsourcing. SMEs play a major role in many countries and not only in the Italian economic system. They account for nearly $99 \%$ of the national. From a survey carried out by the National Institute of Statistics it emerges that the micro-enterprises represent $95.2 \%$ of the Italian entrepreneurial system and account for more than $30 \%$ of its overall turnover. SMEs have become the essence of Italian commerce. Their contribution is visible in the goods and services that they provide and the degree to which they have increased employment and generated income. Since 1950, SMEs' business activities are rapidly expanding throughout Italy. In the fast-changing world of business, SMEs continue to increase their importance as a force for national economic resilience in terms of their contribution towards growth (United Nations Development Programme, 2007).

The technical literature on the logistics of small and medium-sized enterprises is not particularly extensive. The bulk of logistics research still focuses on the logistics of large companies. The first more detailed study of enterprise logistics was that of Heinrich and Felhofer (1985). Almost half a hundred articles and studies have been written on this topic since that time, but the bulk of logistics research still focuses on the logistics of large companies. Probably, this is due to the fact that the logistics functions of large companies are sounder and easier to research (Pearson and Semeijn, 1999). Unfortunatly, SMEs have different organisational settings and are not miniature-versions of large enterprises (Hagelaar et al., 2014).

The research concerning the use of the concept of outsourcing in managing small and medium-sized enterprises has been presented by Matejun (2010). In the survey all the researched enterprises apply the outsourcing concept in their functioning, accountancy and tax settlements, the most often outsourced area. Transport and Logistics are not considered key functions to outsource.

The 90\% of SMEs examined by Vízhányó (2006) thought that logistics meant exclusively transportation and warehousing; $55 \%$ among them regarded purchasing as the start of the process and delivery to the customer as its end. Kummer (1992) studied the interpretation of logistics in more detail by in his research covering 111 members of the Chambers of Commerce and Industry of Koblenz and Dortmund, respectively, active in commerce, metal processing, food and beverages manufacture and construction, and he came to the following conclusions:

- In most cases, respondents consider logistics important, and under the questionnaire-surveys applying mostly the Likert scale, they assign it great significance (Berr et al., 1990; Kummer, 1995).

- The survey of 2006 revealed that medium-sized and smaller enterprises were aware of the relevance of logistics, but their development options were limited (Naula et al., 2006).

SMEs are characterised by a low degree of outsourcing, the underlying reason being the excessive relative transaction costs of the services concerned due to diseconomies of scales; furthermore, the minimum transaction size of the various services also differs. Van den Berg (2009) came to the same conclusion, i.e. that the traditional outsourcing model had been designed for large contracts to achieve economies-of-scale, but with the development of ICTs it is now becoming accessible also to the SMEs.

In terms of SME logistics, capital and management they are always in the hands of the entrepreneur; he is the one who assumes the risks and liabilities, determines the structure down to the least details through his personal 
presence and the enterprise is the essential source of living of the family" and its "revenue" (Beumer et al., 2009).

The outsourcing quickly became widespread in various business domains, so as: administration, finances, marketing, personnel management, logistics, than includes the entire supply chain. Besides the logistics outsourcing practice of large companies and SMEs, the researches tried to find an answer to the extent and reasons of outsourcing by involving both the clients and the service providers. McIvor (2000) declares where a sufficient number of suitable service provider/supplier implying little hazard is available, that is conducive to the strategic outsourcing of the activities. The opposite, i.e. insufficient number of suitable service provider/supplier or little danger of competition in the future, is conducive to own activity.

Rich literature describes advantages/disadvantages of logistics outsourcing, even if researches are based on the examination of large firms. Selviaridis and Spring (2007) assign the relevant reasons to three categories: strategy, finance and operations related.

1. The strategic advantages include most frequently the core competences and focusing on external expertise (e.g. Sink and Langley, 1997). The disadvantages include the loss of logistics competency, of control over this activity and of contact with the clients (e.g. Ellram and Cooper, 1990).

2. The financial advantages are the possibility to make fixed costs variable (e.g. Beumer et al., 2009) or to exploit the economies of scales (e.g. van Damme and Ploos van Amstel, 1996). However, it is not easy to evaluate cost savings given the fact that clients are not always aware of the costs of logistics.

3. The main operational advantages are the decrease of inventory levels, cycle and lead times, and the improvement of client service (e.g. Daugherty et al., 1996), but there are also many disadvantages such as the inadequate expertise of the service provider, the loss of client feedback, inability to handle special needs and emergency circumstances (e.g. Ellram and Cooper, 1990; Sink and Langley, 1997).

\section{The Research Methodology}

The main objective of our study is to determine if SMEs use outsourcing services in logistics, which particular areas are the most often outsourced and what are the main reasons for logistics outsourcing. The research has been developed with the contribution of Confindustria of Padua (Este delegation). Confindustria is the General Confederation of Italian Industry and represents more than 110,000 companies. Confindustria of Padua, with almost 1,600 associated companies, involves over 64,000 people. The sample is composed by 28 small and medium sized enterprises belonging to different industries. We use European classification according to the number of persons employed, and our sample employs more than 30 persons and less than 249 persons employed. Micro enterprises are completely excluded from the research. All enterprises are located in Padua (North East Italy).

The research has been conducted through an empirical analysis of exploratory multiple case study. The choice of the multiple case study method is one of the most appropriate way of empirical inquiry because qualitative studies are necessary where organizational processes are involved. Case study research excels at bringing us to an understanding of a complex issue or object and can extend experience or add strength to what is already known through previous research. The case study is defined by researcher Robert K. Yin as an empirical inquiry that investigates a current phenomenon within its real-life context, especially when the boundaries between phenomenon and context are not clearly (Yin, 1984). Strength of the case study method is that the emergent theory is likely to be testable with constructs that can be readily measured and hypotheses that can be proven false.

The results are based on interviews both with owner and with employees. The interviews were semi-structured to be kept within the main question area but still open the possibility to get the interviewees own ideas and feelings. The interviews also included some questions to verify the good quality of answers (Yin, 1984). The choice of 28 firms is supported by the Eisenhardt's approach to case study research which argues for the use of more than a single case. She concludes that "between 4 and 10 cases usually works well" (Eisenhardt, 1989).

The project has been developed in four stages:

- Stage 1: Project presentation to companies associated to Confindustria of Padua

- Stage 2: Organization of meetings (4). Interviews and discussions with entrepreneurs and managers about their logistics activites. We asked our respondents whether they used outsourcing services in logistics, which specific processes were most often outsourced and what were their positive or negative experiences with logistics outsourcing. 
- Stage 3: Direct interviews with every company. Identification of the reason why companies outsource (or not) their activities and what activities are outsourced.

- Stage 4: Simple logistics costs evaluation. During the interview we requested the costs of basic logistics processes (p.e. unload, reception, storage and picking). After this, we calculated the cost with ABC model and compare the cost comunicated with the cost revealed.

During our interviews we investigate if companies are aware of their:

- Transportation cost

- Warehousing cost

- Picking and Packaging cost

\section{Mains Results}

The main activity the total of companies outsource is the transportation. All companies know very well the amount of costs and choose the 3PLs because they warrant:

- Lower costs of management

- High service quality

- Traceability of goods

Companies are not aware of other costs. SMEs do not calculate warehousing cost or Picking and Packaging costs. In this way companies can not compare a 3PL offer with their internal costs. Moreover the main worries are:

- Lack of control of inventory, even if 3PL warrants a fully visibility throug Internet based platforms. Companies believe they are not able to control the exact amount of goods, because thy haven't a fully control of inventory levels in their warehouses.

- Reduction of flexibility. Many companies permit special customization before the shipment. The customizations don't belong to a process, and they are different every time. Companies are not able to forecast any services to provide to customers.

Table 1. Main results of the research

\begin{tabular}{ll}
\hline Total companies involved in the project & 30 \\
\hline Number of Companies that outsource transport & 28 \\
\hline Companies that outsource warehouse of finished goods & 3 \\
\hline $\begin{array}{l}\text { Companies aware of logistics services provided by 3PL: } \\
\text { Transport, Information Systems, Shipment Planning, }\end{array}$ & 1 \\
Fleet Management, Packaging, Product Returns. \\
\hline $\begin{array}{l}\text { Companies aware of logistics services provided by 3PL: } \\
\text { Transport, Shipment Planning, Fleet Management. }\end{array}$ \\
\hline $\begin{array}{l}\text { Companies afraid about the loose of control of logistics } \\
\text { processes after outsourcing. }\end{array}$ & 8 \\
\hline $\begin{array}{l}\text { Companies that consider outsourcing a service destined } \\
\text { to Large Enterprises }\end{array}$ & 22 \\
\hline Companies aware of their logistics costs & 5 \\
\hline Companies that calculate and check the logistics costs & 1 \\
\hline
\end{tabular}

SMEs do not know all the services that a 3PL can offer. A large percentage of the participants knows the outsourcer provide transport and storage, but SMEs ignore other services such as:

- Freight Payments \& Auditing

- Carrier Selection \& Rate Negotiation

- Information Systems

- Shipment Planning 
- Fleet Management

- Packaging

- Product Returns

Moreover, small enterprises consider the 3PL's services only for structured and large enterprises. During our interviews It's evident that SMEs do not evaluate a collaboration with a logistics provider because they think their services are designed only for large enterprises. We named this factor Ignorance.

In our meeting we ask to managers the exact logistics costs but or they don't answer or their evaluations are not correct. In effect, in our project for every company we calculate the costs using the activity based costing (ABC) model. The concept of $\mathrm{ABC}$ was elaborated to solve the distortion problems of traditional costing systems (Cooper et al., 1988). This method allocates the indirect costs on a cause effect basis instead of using arbitrary cost assignment techniques. La Londe et al (1994) pointed out that after its initial application in manufacturing, $\mathrm{ABC}$ can be a useful tool in logistics management as well. It can measure how products or customers consume logistics resources so the allocation of logistics related overhead costs can be carried out on a more exact basis. In our sample the majority haven't a perception of real process costs. Usually they use only direct cost and most of them omit indirect costs. Their economic survival is warranted by large margins. After our simulation to determine the cost of simple processes (p.e. unload, reception and storage costs), the costs calculated with $\mathrm{ABC}$ model are greater than $40-60 \%$ of SMEs' costs.

Finally, according with a previous study on Italian SMEs, firms consider logistics processes not relevant for their competitivity. Cafferata (2009) affirms that R\&D and design together with marketing play the most important role, while information technologies are mostly used for finance management and organization control. Logistics don't compare in the list of most importance Functional Areas for of SMEs. Probably this is a reason why firms haven't got a good control of logistics costs.

\section{Conclusions}

SMEs outsource the transport and shipment. Thiese two services can represent the first stage of the development towards a more extensive adoption of logistics outsourcing. At moment, other logistics processes are not outsourced because SME don't want lose control of inventory and they are afraid of the flexibility reduction. They consider it is more difficult to communicate with the provider and the time request to react to customer needs should increase. A real critical aspect this paper found on SME is that small and medium companies are not aware of the internal logistics cost. In this way, they cannot compare the service price with their costs and they are not able to decide if the best strategy is the Make or Buy. Moreover, SME do not outsource because:

- They perceive the risk to loose the know-how of the outsourced services.

- They think that 3PLs develop services only for large enterprises.

- They perceive the risk to loose the control of real logistics costs.

This research presents some limits that can be summarized as follows:

- the analysis was conducted using qualitative data which can be affected by subjectivity;

- the number of firms is limited;

- the study considers only SMEs concentrated in a limited territory;

- only few processes are considered to determine the costs.

According with a previous study on Italian SMEs, firms consider logistics processes not relevant for their competitivity.

\section{References}

Aldin, N., \& Stahre, F. (2003). Electronic commerce, marketing channels and logistics platforms - wholesalers perspective. European Journal of Operational Research, 144, 270-9. https://doi.org/10.1016/S0377-2217(02)00393-4

Andersson, D. (1997). Third Party Logistics- Outsourcing Logistics in Partnerships. Linköping Studies in Management and Economics, Dissertation No. 34, Linköping Institute of Technology.

Andersson, D., Dreyer, H.C., Halldórsson, Á., Jahre, M., Ojala, L., Skjoett-Larsen, T., \& Virum, H. (2003). Third Party Logistics - A Nordic Research Approach. Turku: Kirjapaino Grafia Oy. 
Berr, U., Borchert, G., \& Feldhahn, K.A. (1990). Logistikkonzepte in kleinen und mittleren Unternehmen. Logistik im Unternehmen, (6), 30-32.

Beumer C., Furmans, K., Kilger, C., \& Grosche, T. (2009). Logistik im Mittelstand. Best Practices - Strategien für den Erfolg. Deutscher Verkehrs-Verlag, Hamburg.

Bovet, D. (1991, July/August). Logistics strategies for Europe in the 1990s. Planning Review, 12-15.

Chopra, S., \& Meindl, P. (2010). Supply chain management: Strategy, planning and operations. Pearson, Upper Saddle River, NJ.

Commonwealth Business Media Inc. (2006). The 3PL Origin and Evolution. Traffic World, 270(22), 33.

Cooper, J.C. (1993). Logistics strategies for global businesses. International Journal of Physical Distribution \& Logistics Management, 23(4), 12-23. https://doi.org/10.1108/09600039310041473

Cooper, R., \& Kaplan, R. S. (1988). Measure costs right, make the right decisions. Harvard Business Review, 66(5), 96-103.

Daugherty, P.J., Dtank, T.P., \& Rogers, D.S. (1996). Third party logistics service providers: purchaser's perceptions. International Journal of Purchasing and Materials Management, 32(2), 23-29. https://doi.org/10.1111/j.1745-493X.1996.tb00222.x

Ellegaard, C. (2006). Small company purchasing: a research agenda. Journal of Purchasing and Supply Management, 12(5). https://doi.org/10.1016/j.pursup.2006.08.004

Ellram, L.M., \& Cooper, M.C. (1990). Supply chain management, partnerships and the shipper-third party relationship. International Journal of Logistics Management, 30(5), 443-453. https://doi.org/10.1108/95740939080001276

Fawcett, S.E., Birou, L.M., \& Taylor, B.C. (1993). Supporting global operations through logistics and purchasing. International Journal of Physical Distribution \& Logistics Management, 23(4), 3-11. https://doi.org/10.1108/09600039310041464

Hagelaar, G., Staal, A., Holman, R., \& Walhof, G. (2014). An integral framework for studying purchasing and supply management in small companies. Competitive Paper 24th IPSERA Conference, South Africa.

Hamel, G., \& Prahalad, C.K. (1990). The Core Competence of Corporation. Harvard Business Review, 68(3), 79-91.

Hilletofth, P. (2010). Demand-Supply chain management. Chalmers Reproservice, Göteborg Sweden.

Hilletofth, P., \& Hilmola, O. (2010). Role of logistics outsourcing on supply chain strategy and management: Survey findings from Northern Europe. Strategic Outsourcing: An International Journal, 3(1), 46-61.

Hrušecká, D., Macurová, L., Juřičková, E., \& Kozáková, L. (2015). The Analysis of the Use of Outsourcing Services in Logistics by Czech Manufacturing Companies. Journal of Competitiveness, 7(3), 50-61. https://doi.org/10.7441/joc.2015.03.04

John, L. (2014). Third-Party Logistics Study. The State of Logistics Outsourcing. Results and Findings of the 18th Annual Study, CapGemini.

Kummer, S. (1992). Logistik im Mittelstand. Stand und Kontextfaktoren der Logistik im mittelständischen Unternehmen. Schäffer-Poeschel Verlag, Stuttgart.

La Londe, B. J., \& Pohlen, T. L. (1994). Implementing activity-based costing (ABC) in logistics. Journal of Business Logistics, 15(2), 1-23.

Lieb, R.C., Millen, R.A., \& Wassenhove, L.N.V. (1993). Third-party logistics services: a comparison of experienced American and European manufacturers. International Journal of Physical Distribution \& Logistics Management, 23(6), 35-44. https://doi.org/10.1108/09600039310044894

Matejun M. (2010). Application of the Outsourcing Concept in Managing Small and MediumSized Enterprises. Management, 14(2), 77-90.

McFarlan, F.W. (1984). Information technology changing the way you compete. Harvard Business Review, $57(2), 115-26$.

McIvor, R. (2000). A practical framework for understanding the outsourcing process. Supply Chain Management: An International Journal, 5(1), 22-36. https://doi.org/10.1108/13598540010312945 
Morrissey, B., \& Knight, L. (2011). Purchasing in Small Companies - past assumptions, current evidence and future research. Conference Paper IPSERA, Maastricht.

Naula, T., Ojala, L., \& Solakivi, T. (2006). Finland - State of Logistics 2006. Publications of the Ministry of Transport and Communications Finland 45/2006, Edita Publishing, Helsinki.

Persson, G., \& Virum, H. (2001). Growth Strategies for Logistics Service Providers: A Case Study. International Journal of Logistics Management, 12(1), 53-64. https://doi.org/10.1108/09574090110806226

Pollitt, D. (1998). View point: getting logistics on to boardroom agenda. International Journal of Physical Distribution \& Logistics Management, 28(3), 168-9.

Razzaque, M.A., \& Sheng, C.C. (1998). Outsourcing of logistics functions: a literature survey. International Journal of Physical Distribution \& Logistics Management, 28(2), 89-107. https://doi.org/10.1108/09600039810221667

Scott, C., Lundgren, H., \& Thompson, P. (2011). Guide to Supply Chain Management. Springer-Verlag Berlin Heidelberg. https://doi.org/10.1007/978-3-642-17676-0

Selviaridis, K., \& Spring, M. (2007). Third party logistics: a literature review and research agenda. The $\begin{array}{lllll}\text { International Journal of Logistics } & \text { Management, 18(1), }\end{array}$ https://doi.org/10.1108/09574090710748207

Sink, H.L., \& Langley, C.J. (1997). A managerial framework for the acquisition of thirdparty logistics services. International Journal of Physical Distribution \& Logistics Management, 26(3), 38-46. https://doi.org/10.1108/09600039610115009

Trunick, P.A. (1989, July). Outsourcing: a single source for many talents. Transportation \& Distribution, 2023.

United Nations Development Programme. (2007). Annual Report. New York, USA: Office of communication. United Nations Development Programme.

Van Damme, D.A., \& Ploos van Amstel, M.J. (1996). Outsourcing logistics management activities. International Journal of Logistics Management, 7(2), 85-95. https://doi.org/10.1108/09574099610805548

Van den Berg, E. (2009). Outsourcing for SMEs. Credit Management, 24-25.

Vízhányó, A. (2006). A logisztikai outsourcing dilemmái a magyarországi kis- és középvállalkozások körében. Thesis, Budapest.

Wilding, R., \& Juriado, R. (2004). Customer Perceptions on Logistics Outsourcing in the European Consumer Goods Industry. International Journal of Physical Distribution and Logistics Management, 34(8), 628-644. https://doi.org/10.1108/09600030410557767

\section{Copyrights}

Copyright for this article is retained by the author(s), with first publication rights granted to the journal.

This is an open-access article distributed under the terms and conditions of the Creative Commons Attribution license (http://creativecommons.org/licenses/by/4.0/). 